\title{
STUDIES ON KETONE METABOLISM IN MAN. I. A METHOD \\ FOR THE QUANTITATIVE ESTIMATION OF SPLANCHNIC KETONE PRODUCTION ${ }^{1,2}$
}

\author{
BY EMILE E. WERK, JR., ${ }^{3}$ HARRY T. MCPHERSON, ${ }^{4}$ LADD W. HAMRICK, JR., \\ JACK D. MYERS, AND FRANK L. ENGEL \\ (From the Department of Medicine, Duke University, Durham, N. C.)
}

(Submitted for publication January 10, 1955; accepted April 6, 1955)

The phenomenon of ketosis has interested investigators and clinicians for many years. With the recent rapid strides in the understanding of fat metabolism and the central role of acetyl-CoA in intermediary metabolism (1-5), this subject has taken on added interest. Although it has long been recognized that the liver is the chief site of origin of the ketone bodies, the basis for this has only recently been clarified. Apparently, most tissues are capable of forming acetoacetyl-CoA during the normal course of fatty acid catabolism or by condensation of two molecules of acetyl$\mathrm{CoA}$, but only the liver both possesses an enzyme, deacylase, which removes $\mathrm{CoA}$ from the molecule to release free acetoacetate, and at the same time lacks the acetoacetate activating enzyme which would result in acetoacetate's re-entering the metabolic cycle as acetoacetyl-CoA. Other tissues have some deacylase activity, but their acetoacetate activating enzyme system is so active that little or no free acetoacetate ever escapes from the cell (4). Ketonemia thus represents the balance between the rate of ketone production by the liver, utilization by extra hepatic tissues and excretion by the kidneys. Hepatic ketone production in turn is a function of the relative rates at which acetyl-CoA and acetoacetyl-CoA are formed, as from fat catabolism, and amino acids, and the rate at which acetyl-CoA can be disposed of by oxidation via the Krebs cycle or by reduction and syn-

\footnotetext{
1 Presented at the 45th Annual Meeting, the American Society for Clinical Investigation, Atlantic City, N. J., May 4, 1953, (J. Clin. Invest., 1953, 32, 610).

2 Supported in part by research grants from the $\mathrm{Na}$ tional Institute of Arthritis and Metabolic Diseases of the National Institutes of Health, Public Health Service (A142) and from Merck and Company, Rahway, N. J.

3 American Cancer Society Fellow, 1953-1954. Present address: Veterans Administration Hospital, 3200 Vine Street, Cincinnati, Ohio.

4 American College of Physicians Fellow, 1954-1955.

5 American College of Physicians Fellow, 1952-1953.
}

thesis to fat. Whenever the rate of acetyl-CoA formation exceeds that of disposal, two molecules of acetyl-CoA may condense to form acetoacetyl$\mathrm{CoA}$ and this, as well as acetoacetyl-CoA derived directly from fat catabolism, may be released into the general circulation. The two pathways of acetate utilization (oxidation and fat synthesis) are strongly dependent on a relatively high rate of carbohydrate utilization, a fact which accounts for the well known occurrence of ketosis during such states of carbohydrate deprivation as occur during starvation and in diabetes mellitus (5-7).

It is thus apparent that ketone body production by the liver is a reflection of the balance of various forces in the metabolism of acetyl-CoA and hence it might be anticipated that any technique which enabled one to estimate hepatic ketone body production quantitatively should throw some light on the metabolism of this key metabolite in man. This has been made possible by the development of a sensitive method for the analysis of ketone bodies and the availability of a technique for estimating splanchnic blood flow by hepatic venous catheterization and bromsulphalein infusion. Moreover, the introduction by Margen, Michaels, Boling, and Kinsell (8) of sodium octanoate, an eight carbon fatty acid, for intravenous infusion has presented the opportunity of studying changes in splanchnic ketone production after loading with an exogenous precursor for ketone synthesis.

The present study represents the application of these techniques to the estimation of splanchnic ketone balances before and after octanoate infusion in essentially normal humans. It serves as a basis for future studies in this laboratory on the influence of hormones and of various pathological states on ketone metabolism in man.

\section{METHODS}

Twenty-one mildly ill hospital patients between the ages of twenty-three and sixty-two, without known 
metabolic abnormality, fever, or hepatic or renal disease, were used as subjects. Two patients (J. T. and D. B., Table I) were studied in the afternoon six hours post cibum; all others were studied in the morning after an overnight fast. The patients had been eating the regular hospital diet, with the exception of those with a peptic ulcer who had been consuming a liberal ulcer diet. All had been eating well, without recent weight loss, nausea or vomiting.

The patients were sedated with 90 to $120 \mathrm{mg}$. of phenobarbital given orally one to two hours before the studies. To minimize anxiety during the period of study, inlying femoral arterial and forearm venous needles and the hepatic venous catheter were inserted early in the procedure, using local procaine anesthesia, with no added epinephrine. An intravenous infusion of bromsulphalein was started, to be maintained, using a constant infusion pump, throughout the entire time of the study. After the needles and catheter were in place the patients were allowed to rest quietly for ten to fifteen minutes before the painless procedure of sampling was initiated.

A control study was carried out on each subject during which femoral arterial and hepatic venous bloods were each sampled four times, i.e., every five minutes over a fifteen-minute period, for the subsequent determination of bromsulphalein, glucose and total ketone concentrations. A $500 \mathrm{ml}$. infusion of a 1.5 per cent solution of sodium octanoate was then started intravenously through a needle previously inserted and administered at a constant rate over approximately a one-hour period. During this time the blood sampling for the same chemical determinations was repeated four times at fifteen-minute intervals. Blood sampling for oxygen content and oxygen saturation was interspersed at appropriate intervals during both the control and octanoate periods.

The estimated hepatic blood flow (EHBF) was calculated, for both the control and the octanoate periods, from the corrected infusion rates of bromsulphalein and the arterial-hepatic venous differences of bromsulphalein utilizing the formulae of Bradley, Ingelfinger, Bradley, and Curry (9). Arterial blood concentrations of bromsulphalein did not vary by more than $0.035 \mathrm{mg}$. per 100 ml. per minute during the control period, nor by more than $0.042 \mathrm{mg}$. per $100 \mathrm{ml}$. per minute during any octanoate infusion. It is felt that the formula (9) for correcting the infusion rate of bromsulphalein for such variations applies with reasonable accuracy to the experiments herein reported. Bromsulphalein clearance is an expression of the ratio of the corrected infusion rate to the mean arterial concentration for a given period of study. Bromsulphalein clearance is expressed as per cent of normal, using for reference the data previously accumulated in a series of 63 control subjects (10). The net splanchnic glucose production (NSGP) and splanchnic oxygen consumption $\left(\mathrm{SPO}_{2}\right)$ are the products of the hepatic venous-arterial glucose difference in the first case, and the arterial-hepatic venous oxygen difference in the second case, and the respective hepatic blood flow $(10,11)$.

The total ketones of the blood, expressed as acetone (micromoles per $100 \mathrm{ml}$. whole blood), were determined by a modification of the Greenberg and Lester method (12) as described below. The net splanchnic ketone production (NSKP) was calculated by multiplying the hepatic venous-femoral arterial difference in ketone concentration by the EHBF. The term "net" has been used to take into account the fact that some of the organs supplied by the splanchnic circulation may be utilizing ketone bodies. The actual production is attributed to the liver.

The per cent of octanoic acid converted to ketones (per cent conversion) was calculated for each patient as follows :

\section{Per Cent Conversion}

$$
\begin{aligned}
& \mu \mathrm{M} \text { of octanoic acid theoretically required } \\
& \text { for the mean increase in NSKP per min. per } \\
& \text { sq. } M \text { during the sodium octanoate infusion } \\
& =\frac{}{\mu \mathrm{M} \text { octanoic acid infused per min } \mathrm{M} e \mathrm{r}} \times 100 \text {. }
\end{aligned}
$$

It should be noted that this expression, per cent conversion, is calculated from the amount of octanoate delivered to the body as a whole, the portion actually perfusing the liver not being known. It cannot be considered as a true estimate of the liver's capacity to form ketone bodies from octanoate.

The following is an outline of the procedure for the determination of blood ketone bodies embodying the principal changes developed in this laboratory during the past five years as well as one suggested by Michaels, Margen, Liebert, and Kinsell (13). 6

Protein-free blood filtrates are prepared essentially as described by Weichselbaum and Somogyi (14), using $2 \mathrm{ml}$. of unclotted whole blood (sequestren or heparin) laked in $10 \mathrm{ml}$. of distilled water, to which are added 4 $\mathrm{ml}$. of $0.15 \mathrm{~N} \mathrm{Ba}(\mathrm{OH})_{2}$ and $4 \mathrm{ml}$. of 2.5 per cent $\mathrm{ZnSO}_{4}$. $7 \mathrm{H}_{2} \mathrm{O}$. The ketone determination is performed on 1 or $2 \mathrm{ml}$. aliquots of the supernate after centrifugation, depending on the anticipated ketone levels. The entire procedure, except for the photometry, is carried out in $22 \times 150 \mathrm{~mm}$. glass-stoppered pyrex tubes with specially constructed metal clips to hold the stoppers tightly in place during heating. To $2 \mathrm{ml}$. of supernate (or $1 \mathrm{ml}$. of supernate plus $1 \mathrm{ml}$. of distilled water) $0.5 \mathrm{ml}$. of $13.6 \mathrm{~N} \mathrm{H}_{2} \mathrm{SO}_{4}$ is added, the tube shaken and the stopper twisted tightly into place and secured with the metal clip. The tubes are then heated in a mineral oil bath at 110 to $120^{\circ} \mathrm{C}$. on an electric hot plate for ten minutes, following which they are cooled to room temperature. In this step the acetoacetate is decarboxylated to acetone. After cooling, $0.5 \mathrm{ml}$. of 0.4 per cent potassium dichromate is added to each tube and the heating procedure repeated at the same temperature for 30 minutes, resulting in oxidation and decarboxylation of betahydroxybutyric acid to acetone. Greenberg and Lester

\footnotetext{
${ }^{6}$ Modifications made by Mildred G. Engel.
} 
TABLE I

The metabolic effects of intravenously administered sodium octanoate in 16 male subjects *

\begin{tabular}{|c|c|c|c|c|c|c|c|c|c|c|c|c|c|c|}
\hline \multirow[b]{3}{*}{$\begin{array}{l}\text { Pt. } \\
\text { Age } \\
\text { yrs. }\end{array}$} & \multirow{3}{*}{$\begin{array}{l}\text { Diagnosis } \\
\text { Body } \\
\text { surface } \\
\text { area }\end{array}$} & \multirow{3}{*}{$\begin{array}{c}\text { Anxiety } \\
\text { during } \\
\text { test } \\
\text { Remarks }\end{array}$} & \multicolumn{9}{|c|}{ Total ketones ( $\mu M$ acetone $/ 100 \mathrm{ml}$. blood) } & \multirow{2}{*}{\multicolumn{3}{|c|}{$\begin{array}{l}\text { Estimated hepatic } \\
\text { blood flow } \\
m l . \text { blood } / \min . / M^{2}\end{array}$}} \\
\hline & & & \multicolumn{3}{|c|}{ Control } & \multicolumn{3}{|c|}{$\begin{array}{l}\text { During sodium } \\
\text { octanoate }\end{array}$} & \multirow{2}{*}{$\begin{array}{c}\Delta \\
\begin{array}{c}\text { Fem. } \\
\text { art. }\end{array}\end{array}$} & \multirow{2}{*}{ 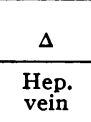 } & \multirow{2}{*}{$\frac{\Delta}{\underset{\text { F.V. }}{\text { F.A. }}}$} & & & \\
\hline & & & $\begin{array}{l}\text { Fem. } \\
\text { art. }\end{array}$ & $\begin{array}{l}\text { Hep. } \\
\text { vein }\end{array}$ & $\underset{\text { F.A. }}{\text { H.V. }}$ & $\begin{array}{l}\text { Fem. } \\
\text { art. }\end{array}$ & $\begin{array}{l}\text { Hep. } \\
\text { vein }\end{array}$ & $\underset{\text { F.V. }}{\text { H.V. }}$ & & & & $\begin{array}{l}\text { Con- } \\
\text { trol }\end{array}$ & $\begin{array}{l}\text { During } \\
\text { sod. } \\
\text { oct. }\end{array}$ & $\Delta$ \\
\hline J. R. & $\begin{array}{c}\text { Functional } \\
\text { G.I. } \\
\mathbf{1 . 8 7}\end{array}$ & $2+$ & 16.5 & 20.3 & 3.8 & 47.2 & 71.5 & 24.3 & +30.6 & +51.2 & +20.6 & 673 & 579 & -94 \\
\hline J. V. & $\begin{array}{c}\text { Chronic } \\
\text { anxiety } \\
2.02\end{array}$ & $1+$ & 17.0 & 22.8 & 5.8 & 46.5 & 65.8 & 19.3 & +29.5 & +43.0 & +13.5 & 750 & 713 & -37 \\
\hline T. $\underset{25}{M c}$ & $\begin{array}{l}\text { ? Mild } \\
\text { rheumatoid } \\
\text { arthritis } \\
1.72\end{array}$ & $1+$ & 4.8 & 7.6 & 2.8 & 39.2 & 67.5 & 28.3 & +34.4 & +59.9 & +25.5 & 576 & 515 & -61 \\
\hline A. P. & $\begin{array}{c}\text { Chr. duod. } \\
\text { ulcer } \\
1.84\end{array}$ & $1+$ & 16.0 & 19.0 & 3.0 & 38.0 & 61.5 & 23.5 & +22.0 & +42.5 & +20.5 & 678 & 774 & +96 \\
\hline R. M. & Post U.R.I. & $1+$ & 9.2 & 10.7 & 1.5 & 38.2 & 62.0 & 23.8 & +29.0 & +51.3 & +22.3 & 708 & 660 & -48 \\
\hline E. S. & $\begin{array}{c}\text { Duodenal } \\
\text { ulcer } \\
\mathbf{1 . 5 5}\end{array}$ & $1+$ & 10.5 & 14.8 & 4.3 & 65.2 & 87.3 & 22.1 & +54.7 & +72.5 & +17.8 & 974 & 797 & -177 \\
\hline W. J. & $\begin{array}{c}\text { Carcinoma } \\
\text { sphenoid } \\
\text { sinus } \\
1.84\end{array}$ & $1+$ & 14.8 & 22.0 & 7.2 & 43.2 & 69.5 & 26.3 & +28.4 & +47.4 & +19.0 & 923 & 782 & -141 \\
\hline E. S. & $\begin{array}{c}\text { Chronic } \\
\text { sinusitis } \\
1.77\end{array}$ & $1+$ & 9.0 & 12.0 & 3.0 & 32.0 & 61.0 & 29.0 & +23.0 & +49.0 & +26.0 & 785 & 708 & -77 \\
\hline J. ${ }_{58}^{\prime} N$ & $\begin{array}{c}\text { Mixed } \\
\text { psycho- } \\
\text { neurosis } \\
1.72\end{array}$ & $1+$ & 19.5 & 25.5 & 6.0 & 50.2 & 67.5 & 17.3 & +30.7 & +42.0 & +11.3 & 713 & 686 & -27 \\
\hline G. W. & $\begin{array}{c}\text { Headache } \\
1.56\end{array}$ & $1+$ & 10.5 & 12.3 & 1.8 & 47.0 & 69.5 & 22.5 & +36.5 & +57.2 & +20.7 & 906 & 784 & -122 \\
\hline J. T. & $\begin{array}{c}\text { Headache } \\
1.65\end{array}$ & $\begin{array}{c}2+ \\
6 \mathrm{hr} \text {. fast }\end{array}$ & 14.5 & 23.0 & 8.5 & 44.5 & 73.0 & 28.5 & +30.0 & +50.0 & +20.0 & 510 & 594 & +84 \\
\hline T. J. & $\begin{array}{c}\text { ? Cord tumor } \\
1.67\end{array}$ & $1+$ & 6.5 & 9.8 & 3.3 & 26.0 & 42.5 & 16.5 & +19.5 & +37.7 & +18.2 & 1,027 & 1,227 & +200 \\
\hline O. A. & $\begin{array}{l}\text { Post } \\
\text { erythema } \\
\text { nodosum } \\
\mathbf{1 . 8 5}\end{array}$ & $1+$ & 14.5 & 17.8 & 3.3 & 32.8 & 50.0 & 17.2 & +18.3 & +32.2 & +13.9 & 986 & 827 & -159 \\
\hline J. V. & $\begin{array}{c}\text { Duod. ulcer } \\
1.81\end{array}$ & $1+$ & 7.0 & 6.5 & -0.5 & 31.3 & 47.8 & 16.5 & +24.3 & +41.3 & +17.0 & 698 & 608 & -90 \\
\hline D. B. & $\begin{array}{c}\text { Brachial } \\
\text { plexus } \\
\text { palsy } \\
1.64\end{array}$ & $\underset{6 \mathrm{hr} . \text { fast }}{1+}$ & 31.5 & 39.0 & 7.5 & 59.3 & 83.0 & 23.7 & +27.8 & +44.0 & +16.2 & 890 & 668 & -222 \\
\hline J. W. & $\begin{array}{l}\text { Functional } \\
\text { G.I. } \\
1.59\end{array}$ & $2+$ & 24.0 & 32.0 & 8.0 & 40.5 & 58.3 & 17.8 & +16.5 & +26.3 & +9.8 & 840 & 788 & -52 \\
\hline $\begin{array}{c}\text { Mean } \\
\text { Age } \\
37 \\
\text { Range } \\
23-62\end{array}$ & $\begin{array}{l}\text { Mean } \\
\text { S.A. } \\
1.74\end{array}$ & $\begin{array}{l}\text { Mean } \\
\text { S.E. } \\
\text { S.D. } \\
\text { P. }\end{array}$ & $\begin{array}{r}14.1 \\
1.73 \\
6.92\end{array}$ & $\begin{array}{r}18.4 \\
2.24 \\
8.96\end{array}$ & $\begin{array}{r}4.3 \\
0.62 \\
2.46 \\
<0.01\end{array}$ & $\begin{array}{c}42.6 \\
2.56 \\
10.25\end{array}$ & $\begin{array}{r}64.8 \\
2.94 \\
11.79\end{array}$ & $\begin{array}{r}22.2 \\
1.10 \\
4.40 \\
<0.01\end{array}$ & $\begin{array}{r}+28.5 \\
2.26 \\
9.01 \\
<0.01\end{array}$ & $\begin{array}{r}+46.4 \\
2.83 \\
11.31 \\
<0.01\end{array}$ & $\begin{array}{r}+17.9 \\
1.19 \\
4.77 \\
<0.01\end{array}$ & $\begin{array}{l}790 \\
38.0 \\
151.7\end{array}$ & $\begin{array}{c}732 \\
40.1 \\
160.4\end{array}$ & $\begin{array}{c}-58.0 \\
27.15 \\
108.6 \\
<0.1 \\
>0.05\end{array}$ \\
\hline
\end{tabular}

* The means shown for each subject regarding Total Ketone Levels, Hepatic Vein -Femoral Artery differences, EH BF, NSKP, Femoral Artery Glucose and NSGP represent the average of four interval samples and four separate calculations. The means for the SpO 2 represent the average of two interval samples and two separate calculations.

carried out the above reactions as a single step with acid dichromate, but Michaels, Margen, Liebert, and Kinsell found that there were unpredictable losses of acetoacetate and poor recovery of beta-hydroxybutyrate on heating in acid-dichromate and hence they introduced the two-step procedure. Our experience confirmed that of the latter investigators so this modification was incorporated.
Appropriate acetone standards containing 2 to 5 micrograms per ml., and prepared according to the method outlined by Hawk, Oser, and Summerson (15), are then placed in glass stoppered tubes to which have been added $0.5 \mathrm{ml}$. of $13.6 \mathrm{~N} \mathrm{H}_{2} \mathrm{SO}_{4}$ and $0.5 \mathrm{ml}$. of 0.4 per cent potassium dichromate. Blanks are prepared with distilled water. One half $\mathrm{ml}$. of 5 per cent anhydrous sodium sulfite, prepared fresh daily, is added to all tubes 
TABLE I-Continued

The metabolic effects of intravenously administered sodium octanoate in 16 male subjects

\begin{tabular}{|c|c|c|c|c|c|c|c|c|c|c|c|c|c|c|c|}
\hline \multicolumn{3}{|c|}{$\begin{array}{c}\text { Net splanchnic ketone } \\
\text { production } \\
\mu M \text { acetone } / \text { min. } / M^{2}\end{array}$} & \multicolumn{3}{|c|}{$\begin{array}{l}\text { Net splanchnic oxygen } \\
\text { consumption } \\
\text { ml./min./M }\end{array}$} & \multirow{2}{*}{$\begin{array}{c}\% \\
\text { conver- } \\
\text { sion sod. } \\
\text { oct. to } \\
\text { ketones }\end{array}$} & \multicolumn{3}{|c|}{$\begin{array}{l}\text { Femoral artery } \\
\text { glucose } \\
\text { mg./100 ml. blood }\end{array}$} & \multicolumn{3}{|c|}{$\begin{array}{c}\text { Net splanchnic glucose } \\
\text { production } \\
\text { mg./min./M' }\end{array}$} & \multicolumn{3}{|c|}{ \% BSP clearance } \\
\hline $\begin{array}{l}\text { Con- } \\
\text { trol }\end{array}$ & $\begin{array}{l}\text { During } \\
\text { sod. } \\
\text { oct. }\end{array}$ & $\Delta$ & $\begin{array}{l}\text { Con- } \\
\text { trol }\end{array}$ & $\begin{array}{l}\text { During } \\
\text { sod. } \\
\text { oct. }\end{array}$ & $\Delta$ & & $\begin{array}{l}\text { Con- } \\
\text { trol }\end{array}$ & $\begin{array}{l}\text { During } \\
\text { sod. } \\
\text { oct. }\end{array}$ & $\Delta$ & $\begin{array}{c}\text { Con- } \\
\text { trol }\end{array}$ & $\begin{array}{l}\text { During } \\
\text { sod. } \\
\text { oct. }\end{array}$ & $\Delta$ & $\begin{array}{c}\text { Con- } \\
\text { trol }\end{array}$ & $\begin{array}{l}\text { During } \\
\text { sod. } \\
\text { oct. }\end{array}$ & $\Delta$ \\
\hline 26 & 140 & +114 & 33 & 37 & +4 & 15 & 80 & 78 & -2 & 50 & 50 & 0 & 76 & 72 & -4 \\
\hline 43 & 137 & +94 & 37 & 36 & -1 & 13 & 92 & 90 & -2 & 61 & 44 & -17 & 78 & 77 & -1 \\
\hline 16 & 145 & +129 & 28 & 34 & +6 & 15 & 78 & 77 & -1 & 49 & 44 & -5 & 82 & 82 & $\mathbf{0}$ \\
\hline 22 & 180 & +158 & 28 & 39 & +11 & 20 & 83 & 80 & -3 & 64 & 60 & -4 & 75 & 70 & -5 \\
\hline 5 & 158 & +153 & 35 & 35 & 0 & 18 & 76 & 74 & -2 & 61 & 46 & -15 & 76 & 75 & -1 \\
\hline 42 & 170 & +128 & 31 & 36 & +5 & 14 & 83 & 83 & 0 & 83 & 44 & -39 & 73 & 68 & -5 \\
\hline 66 & 203 & +137 & 46 & 40 & -6 & 17 & 81 & 78 & -3 & 96 & 72 & -24 & 86 & 83 & -3 \\
\hline
\end{tabular}

\begin{tabular}{llllllllllllllllll}
\hline 24 & 204 & +180 & - & - & - & 22 & 105 & 100 & -5 & 108 & 87 & -21 & 64 & - & - & & \\
\hline 43 & 119 & +76 & 38 & 42 & +4 & 9 & 79 & 78 & -1 & 48 & 58 & +10 & 83 & 75 & -8 &
\end{tabular}

\begin{tabular}{|c|c|c|c|c|c|c|c|c|c|c|c|c|c|c|c|}
\hline 15 & 176 & +161 & 32 & 36 & +4 & 17 & 82 & 76 & -6 & 52 & 66 & +14 & 109 & 109 & 0 \\
\hline 40 & 173 & +133 & 34 & 42 & +8 & 16 & 87 & 84 & -3 & 71 & 58 & -13 & 109 & 103 & -6 \\
\hline 34 & 163 & +129 & 30 & 45 & +15 & 15 & 75 & 71 & -4 & 68 & 98 & +30 & 97 & 95 & -2 \\
\hline 32 & 142 & +110 & 56 & 58 & +2 & 14 & 90 & 83 & -7 & 90 & 121 & +31 & 98 & 98 & 0 \\
\hline
\end{tabular}

\begin{tabular}{llllllllllllllll}
\hline $0 ?$ & 101 & +101 & 46 & 42 & -4 & 13 & 84 & 80 & -4 & 68 & 41 & -27 & 86 & 81 & -5 \\
\hline 67 & 158 & +91 & 39 & 42 & +3 & 10 & 90 & 86 & -4 & 67 & 52 & -15 & 81 & 77 & -4
\end{tabular}

\begin{tabular}{|c|c|c|c|c|c|c|c|c|c|c|c|c|c|c|c|}
\hline 68 & 159 & +91 & 29 & 40 & +11 & 10 & 88 & 88 & 0 & 52 & 99 & +47 & 77 & 68 & -9 \\
\hline $\begin{array}{c}34.0 \\
5.20 \\
20.86\end{array}$ & $\begin{array}{r}158.0 \\
6.86 \\
27.46\end{array}$ & $\begin{array}{c}+124 \\
7.36 \\
41.4 \\
<0.01\end{array}$ & $\begin{array}{r}36.1 \\
2.05 \\
7.94\end{array}$ & $\begin{array}{r}40.3 \\
1.52 \\
5.83\end{array}$ & $\begin{array}{r}+4.2 \\
1.46 \\
5.66 \\
<0.02 \\
>0.01\end{array}$ & $\begin{array}{c}14.9 \\
0.88 \\
3.46\end{array}$ & $\begin{array}{l}84.6 \\
1.87 \\
7.46\end{array}$ & $\begin{array}{l}81.6 \\
1.76 \\
7.05\end{array}$ & $\begin{array}{r}-3.0 \\
0.5 \\
2.01 \\
<0.01\end{array}$ & $\begin{array}{r}68.0 \\
4.47 \\
17.92\end{array}$ & $\begin{array}{c}65.0 \\
6.0 \\
24.08\end{array}$ & $\begin{array}{c}-3.0 \\
5.48 \\
21.82 \\
>0.5\end{array}$ & $\begin{array}{c}84.4 \\
3.19 \\
12.81\end{array}$ & $\begin{array}{r}82.2 \\
3.32 \\
13.04\end{array}$ & $\begin{array}{r}-3.4 \\
0.73 \\
2.85 \\
<0.01\end{array}$ \\
\hline
\end{tabular}

to destroy the excess potassium dichromate. After mixing add $2 \mathrm{ml}$. of 2,4 dinitrophenylhydrazine $(0.1$ per cent in $2 \mathrm{~N} \mathrm{HCl}$ ), shake and then introduce exactly $2.0 \mathrm{ml}$. of reagent grade carbon tetrachloride 7 into each tube. A calibrated automatic filling, reservoir type of pipette is the most convenient for this purpose.

${ }^{7}$ Each new lot of carbon tetrachloride should be tested since some yield high blanks with 2,4 dinitrophenylhydrazine. These should not be used.
The tubes are then placed in a large mechanical shaker, 8 and are shaken for 10 minutes. The shaking can be carried out using a standard general purpose reciprocating type shaker ${ }^{\theta}$ at top speed, but one hour is necessary for complete extraction. After shaking, the super-

8 International Equipment Company, Bottle Shaker, Size 2, with specially designed screw-topped adapters fitted to hold 40 of the glass-stoppered tubes.

9 A. H. Thomas Company, No. 8917A. 
natant acid solution is drawn off with suction and discarded. The carbon tetrachloride layer is washed with distilled water and the water layer sucked off. This washing is repeated a second time after which $3 \mathrm{ml}$. of $0.5 \mathrm{~N} \mathrm{NaOH}$ are added to each sample. The tubes are shaken again for 3 minutes in the standard general purpose shaker and the contents then are poured into small standardized tubes (Wassermann tubes) and the color in the lower carbon tetrachloride layer read at 420 millimicrons in a Coleman Jr. Spectrophotometer.

Seasonal temperature changes may cause changes in the blanks and standards because of the nature of the solvent, but in an air-conditioned laboratory this has been no problem. It is important to avoid the use of acetone in the same laboratory where these determinations are being carried out, as acetone is readily taken up from the air by the filtrates and certain of the reagents. It should also be noted that acetone can also be picked up from other laboratories by air conditioning or other ventilating devices. In our experience, this has been a major cause for gross variations in the results.

The reproducibility of the ketone method, tested by comparing 23 random duplicate values, was found to be within 6 per cent for the control range of levels and within 9 per cent for the elevated levels induced by sodium octanoate infusion.

The modification, according to Michaels, Margen, Liebert, and Kinsell (13) noted above, was introduced after the present study had already been initiated, but seemed worthy of adoption since it reputedly gave higher yields of acetone from beta-hydroxybutyrate. On comparing the single acid-dichromate procedure with the two-step heating method (13) in identical samples of filtrates from nine subjects in this study, the latter modification resulted in a small but significantly $(P<0.01)$ greater yield of total blood ketones. The difference increased as the total concentration of ketones rose. However, when ketone levels of different groups of subjects were compared in relation to the two techniques the means were practically identical. Thus, the biological scatter apparently exceeded the small difference in the two methods. For the purpose of this study it seemed sufficiently accurate to incorporate the data from the initial series of subjects whose blood ketones had been determined without the Michaels modification with those from the more recent group of subjects where the change had been made.

One final question arose in regard to the ketone method, namely whether the higher levels obtained during the sodium octanoate infusion could possibly be due to the formation and release by the liver of beta-ketooctanoic acid. Beta-keto-octanoic acid should form a colored hydrazone with 2,4 dinitrophenylhydrazine and hence interfere with the determination of ketone bodies. If beta-keto-octanoic acid were present in filtrates from blood collected during the sodium octanoate period, it should give the color reaction with acid 2,4 dinitrophenylhydrazine after gentle heating to evaporate all the free acetone, and without treating the filtrates with acid and dichromate. Accordingly, filtrates obtained from each

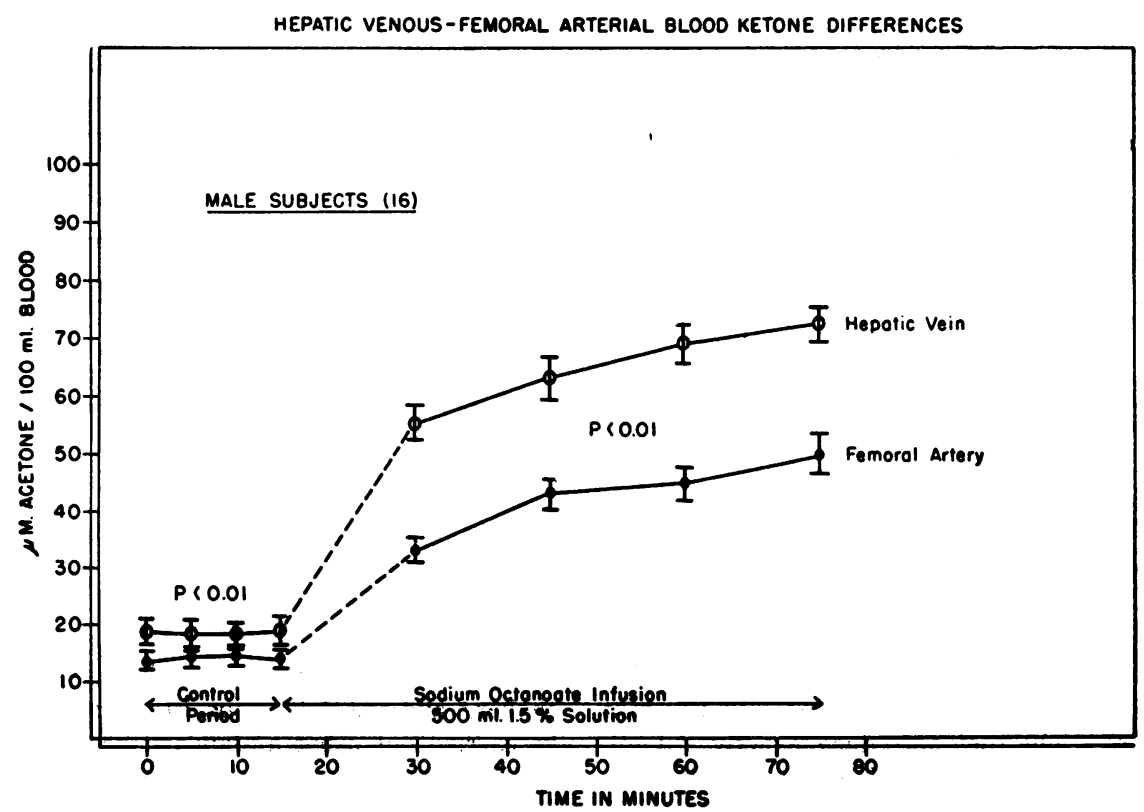

Fig. 1. Hepatic Venous and Femoral Arterial Blood Ketone levels in 16 Male SubJects (Mean \pm S.E.)

The $p$ values refer to the mean hepatic vein-femoral artery ketone differences during the entire control and experimental periods. 


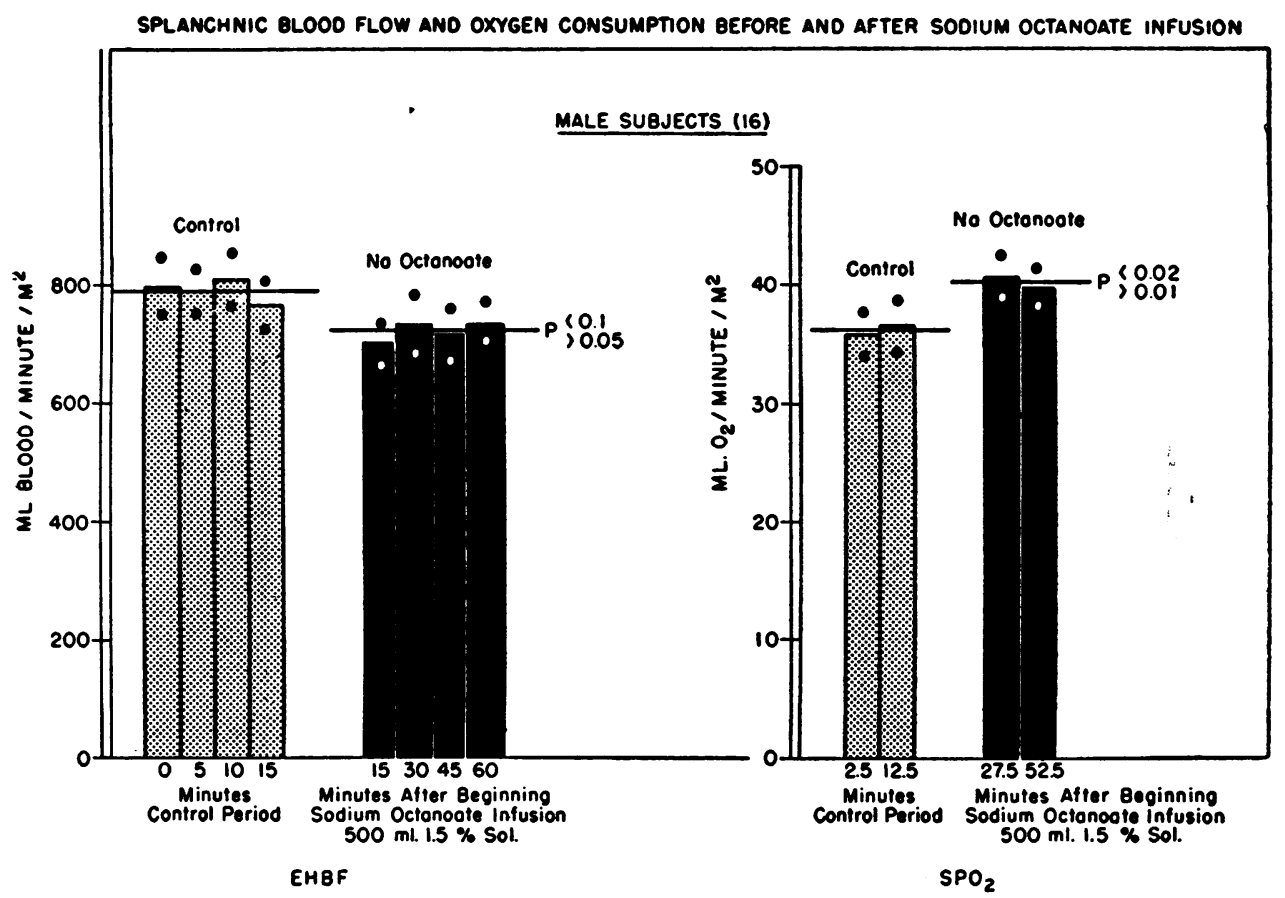

Fig. 2. Estimated Hepatic Blood Flow and Net Splanchnic Oxygen Consumption in 16 Male Subjects (Mean \pm S.E.)

The long horizontal lines represent the mean values for the entire control and experimental periods, and the $p$ values indicate the statistical significance between these means. In the EHBF studies, although there was no significant difference in the mean values for the control and experimental period, the flow during the first 15 minutes after $\mathrm{Na}$ octanoate was significantly decreased $(\mathrm{p}<0.01)$.

of three subjects after sodium octanoate were pooled and tested. No color developed, eliminating the possibility of beta-keto-octanoic acid being present in any significant quantity.

\section{RESULTS}

\section{Male series}

The data on the 16 male subjects are recorded in Table $I$ and Figures 1, 2, 3, and 4. The mean control ketone level in femoral arterial blood was $14.1 \pm 1.73 \mu \mathrm{M}$ per cent (standard error of the mean) and in hepatic venous blood $18.4 \pm 2.24$ $\mu \mathrm{M}$ per cent. The mean difference of $4.3 \pm 0.62$ $\mu \mathrm{M}$ per cent represents a statistically significant $(p<.01)$ elevation of the hepatic venous level over the femoral arterial value. In three subjects (R. M., G. W., and J. V.) the hepatic venous ketone level was not significantly different from the corresponding femoral arterial level, as judged by the limit of error of the ketone method. In all other subjects there was a distinctly meas- urable hepatic venous femoral arterial blood ketone difference. This is illustrated in Figure 1 which depicts the mean values at each period of sampling.

Following the infusion of $500 \mathrm{ml}$. of a 1.5 per cent solution of sodium octanoate there was a brisk increase in the ketone levels of hepatic venous blood $(64.8 \pm 2.94 \mu \mathrm{M}$ per cent), in femoral arterial blood ( $42.6 \pm 2.56 \mu \mathrm{M}$ per cent), and in the hepatic venous-femoral arterial difference (22.2 $\pm 1.10 \mu \mathrm{M}$ per cent). The increase over the control in each case was highly significant statistically $(p<.01)$. The increment in the hepatic venous ketone value was much greater than that of femoral arterial blood. This situation must represent a greatly augmented output of ketone bodies by the splanchnic area, provided there was no great fall in the estimated hepatic blood flow. The data recorded in Table I and Figure 2 indicate that, although there was a quite small but significant fall $(p<.01)$ in the esti- 


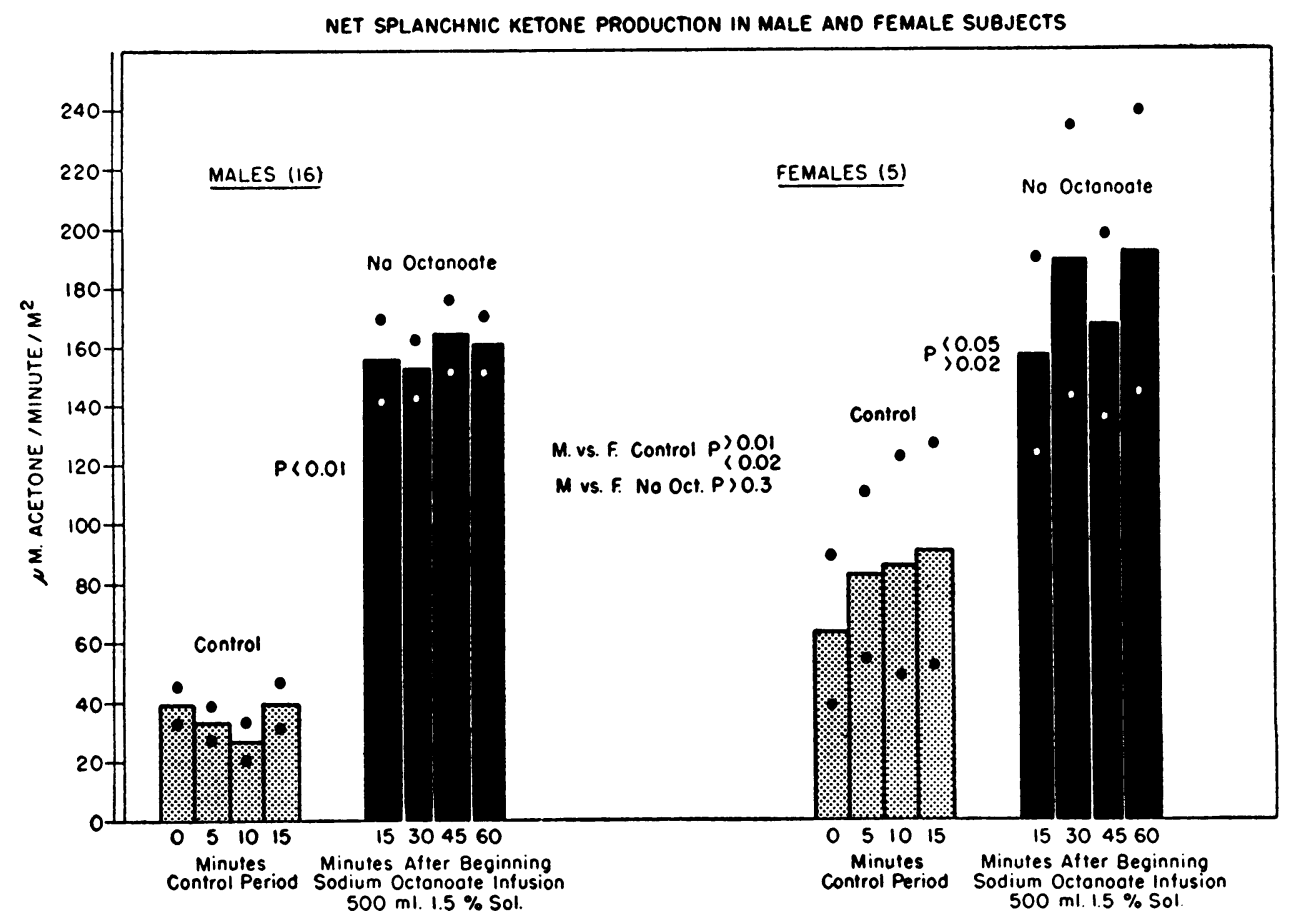

Fig. 3. Net Splanchnic Ketone Production in 16 Male and 5 Female Subjects $(\mathrm{MEAN} \pm$ S.E. $)$

The $\mathrm{p}$ values relate to the mean NSKP during the entire control and experimental periods.

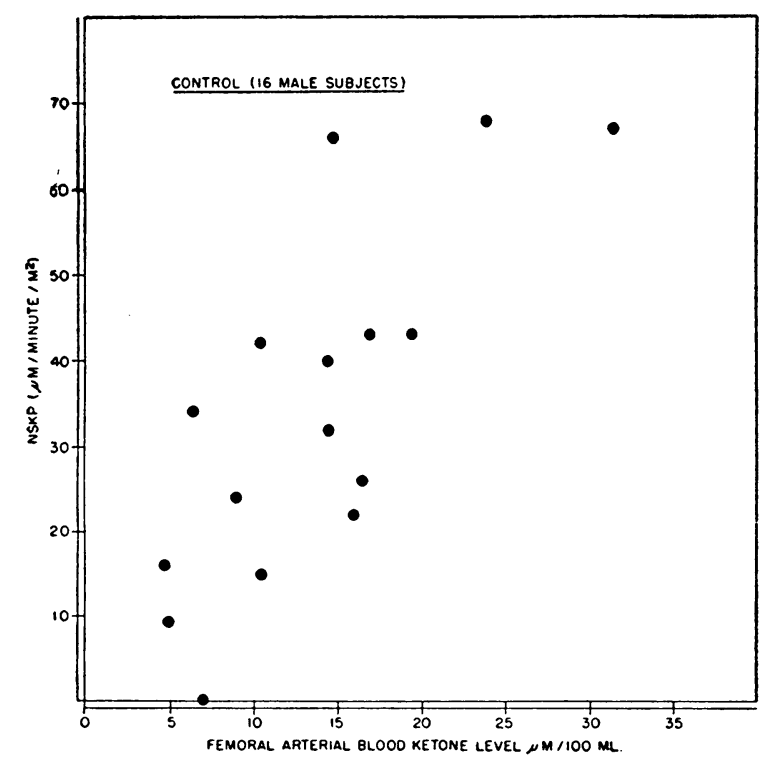

Fig. 4. Relationship of Femoral Arterial Blood Ketone Levels to NSKP in 16 Male Subjects During THE Control Period

Correlation coefficient, $\mathrm{r}=+0.71$. mated hepatic blood flow during the first $15 \mathrm{~min}$ utes of sodium octanoate infusion, this was not progressive.

From the estimated hepatic blood flow and the hepatic venous-femoral arterial blood ketone difference it is possible to calculate the net splanchnic ketone production (NSKP). This appears in Table I and Figure 3. During the control period there was a mean NSKP amounting to $34.0 \pm$ $5.20 \mu \mathrm{M}$ acetone per min. per $\mathrm{M}^{2}$ and this increased to $158 \pm 6.86 \mu \mathrm{M}$ acetone per min. per $\mathrm{M}^{2}$ during the infusion of sodium octanoate. The mean increase of $124 \pm 7.36 \mu \mathrm{M}$ acetone per min. per $\mathrm{M}^{2}$ is, of course, highly significant statistically.

A close correlation $(\mathrm{R}=+0.71, \mathrm{p}<.01)$ was found between the arterial blood ketone levels and the NSKP during the basal period (Figure 4). No such correlation could be demonstrated between the arterial blood ketone values and the NSKP during the period of sodium octanoate infusion.

The per cent of infused sodium octanoate con- 
verted to ketone bodies was calculated to be 14.9 \pm 0.88 per cent, an appreciable figure considering that many tissues besides the liver were perfused by the octanoate.

During the infusion of sodium octanoate the oxygen consumption of the splanchnic area increased by only $4.2 \pm 1.46 \mathrm{ml}$. per min. per $\mathrm{M}^{2}$ (Figure 2 and Table I). As depicted in Figure 2 most of this small rise took place during the first half of the octanoate infusion and then fell off somewhat. No correlation could be made between the rise in $\mathrm{SPO}_{2}$ and NSKP, either collectively or when broken down into the separate sampling periods. Correlation coefficients were +0.254 , +0.207 , and +0.353 , respectively. This is not surprising, since the production of $124 \mu \mathrm{M}$ acetone per min. per $\mathrm{M}^{2}$ by the 16 male subjects would require only $1.9 \mathrm{ml} . \mathrm{O}_{2}$ per min. per $\mathrm{M}^{2}$, or about one-half of the recorded increment in oxygen consumption. The remainder might possibly be attributed to complete oxidation of the fatty acid, which would require more oxygen.

Measurement of the femoral arterial blood glucose levels demonstrated a small fall $(3.0 \pm 0.5$ mg. per cent) during the fatty acid infusion (Table I). This was statistically significant $(p<.01)$ and presumably can be attributed to hemodilution. The net splanchnic glucose production was not modified by the infusion.

Bromsulphalein clearances were generally within the normal range or mildly subnormal, as could be expected in slightly ill subjects, during the control period. They exhibited a small, but significant $(\mathrm{p}<.01)$ decrement during the infusion of the sodium octanoate (Table I). The mechanism of this fall is not immediately apparent unless the simultaneous oxidation of fatty acids by the liver interferes with the mechanism for removing bromsulphalein.

\section{Female subjects}

(Table II, Figures 3 and 5.) Five female subjects were studied and compared to the males, bringing out certain minor differences between the two groups. However, in view of the small sample these differences must be accepted with caution, particularly since they may be accounted for largely by two subjects. As a group the females showed a somewhat higher hepatic venous blood ketone level and a greater hepatic venous-femoral arterial blood ketone difference than the males, although both values were of borderline significance. Since the estimated hepatic blood flow was not different in the two sexes, the females exhibited a somewhat greater basal NSKP than the males $(p<.02)$. As a group the females showed approximately the same increase in NSKP as the males during the infusion of sodium octanoate although there was one subject (F. S.) who exhibited no change in hepatic venous-femoral arterial blood ketone difference or in NSKP during the octanoate infusion. This patient showed an unusually high basal NSKP, but one cannot relate this to the failure to respond to sodium octanoate since another patient (A. M.) had a comparably high basal NSKP and still responded briskly to octanoate. In all other respects there was no demonstrable difference between the males and the females.

\section{DISCUSSION}

The primary objective of this study was to develop a method which would quantitate splanchnic ketone production in man. It was found that after an overnight fast a small but significant endogenous production of ketone bodies was demonstrable in the splanchnic area and that this was notably increased by an intravenous infusion of a known ketone precursor, sodium octanoate. The sudden influx of a comparatively large amount of fatty acid increased hepatic ketogenesis presumably because it could not be converted to fat rapidly enough and hence was degraded to acetoacetyl-CoA and/or acetyl-CoA. The latter was not completely oxidized via the Krebs cycle and hence spilled over into the blood stream as acetoacetate.

In this study the ketosis induced by sodium octanoate occurred promptly. This indicates that the numerous enzymatic steps, which are required for fatty acid catabolism and the hepatic release of free acetoacetate, are accomplished rapidly and without delay in the intact human $(2-5,16-21)$. The findings of Lipsky, Alper, Rubini, Van Eck, and Gordon (22) are in disagreement in that these investigators found a delay of two to four hours in the ketosis induced by the administration of intravenous sodium acetate to humans. How- 
TABLE II

The metabolic effects of intravenously administered sodium octanoate in five female subjects

\begin{tabular}{|c|c|c|c|c|c|c|c|c|c|c|c|c|c|c|}
\hline \multirow[b]{3}{*}{$\begin{array}{l}\text { Pt. } \\
\text { yrs. }\end{array}$} & \multirow{3}{*}{$\begin{array}{l}\text { Diagnosis } \\
\text { Body } \\
\text { surface } \\
\text { area }\end{array}$} & \multirow{3}{*}{$\begin{array}{l}\text { Anxiety } \\
\text { during } \\
\text { test } \\
\text { Remarks }\end{array}$} & \multicolumn{9}{|c|}{ Total ketones ( $\mu M$ acetone $/ 100 \mathrm{ml}$. blood) } & \multirow{2}{*}{\multicolumn{3}{|c|}{$\begin{array}{l}\text { Estimated hepatic } \\
\text { blood flow } \\
\mathrm{ml} . \text { blood } / \min . / M^{2}\end{array}$}} \\
\hline & & & \multicolumn{3}{|c|}{ Control } & \multicolumn{3}{|c|}{$\begin{array}{c}\text { During sodium } \\
\text { octanoate }\end{array}$} & \multirow{2}{*}{$\frac{\Delta}{\begin{array}{c}\text { Fem. } \\
\text { art. }\end{array}}$} & \multirow{2}{*}{$\frac{\Delta}{\begin{array}{c}\text { Hep. } \\
\text { vein }\end{array}}$} & \multirow{2}{*}{$\frac{\Delta}{\underset{\text { F.V. }}{\text { F. }}-}$} & & & \\
\hline & & & $\begin{array}{l}\text { Fem. } \\
\text { art. }\end{array}$ & $\begin{array}{l}\text { Hep. } \\
\text { vein }\end{array}$ & $\underset{\text { F.A. }}{\text { F.A. }}$ & $\begin{array}{l}\text { Fem. } \\
\text { art. }\end{array}$ & $\begin{array}{l}\text { Hep. } \\
\text { vein }\end{array}$ & $\underset{\text { F.A. }}{\text { H.V. }}$ & & & & \multicolumn{3}{|c|}{ 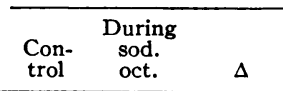 } \\
\hline C. ${ }_{38}^{H}$. & $\begin{array}{c}\text { Labyrinthitis } \\
1.70\end{array}$ & $1+$ & 17.8 & 24.5 & 6.7 & 48.0 & 67.8 & 19.8 & +30.2 & +43.3 & +13.1 & 697 & 588 & -109 \\
\hline F. S. & $\begin{array}{l}\text { Mixed psy- } \\
\text { choneurosis } \\
1.71\end{array}$ & $2+$ & 13.8 & 34.3 & 20.5 & 30.8 & 48.6 & 17.8 & +17.0 & +14.2 & -2.8 & 892 & 934 & +42 \\
\hline A. $M$. & $\begin{array}{l}\text { Chronic otitis } \\
\text { media } \\
\mathbf{1 . 7 2}\end{array}$ & $2+$ & 28.5 & 46.5 & 18.0 & 76.5 & 121.0 & 44.5 & +48.0 & +74.7 & +26.7 & 828 & 602 & -226 \\
\hline W. R. & $\begin{array}{c}\text { Headache } \\
1.71\end{array}$ & $1+$ & 18.0 & 20.2 & 2.2 & 50.5 & 67.5 & 17.0 & +32.5 & +47.3 & +14.8 & 1,130 & 1,150 & +20 \\
\hline C. $\mathrm{R}$. & $\begin{array}{l}\text { Mild } \\
\text { rheumatoid } \\
\text { arthritis } \\
1.69\end{array}$ & $2+$ & 18.0 & 22.0 & 4.0 & 50.0 & 72.0 & 22.0 & +32.0 & +50.0 & +18.0 & 687 & 574 & -113 \\
\hline $\begin{array}{c}\text { Mean } \\
\text { age } \\
35.4 \\
\text { Range } \\
30-47 \\
\end{array}$ & $\begin{array}{l}\text { Mean } \\
\text { S.A. } \\
\text { 1.71 }\end{array}$ & $\left\{\begin{array}{l}\text { Mean } \\
\text { S.E. } \\
\text { S.D. }\end{array}\right.$ & $\begin{array}{r}19.2 \\
2.45 \\
5.49\end{array}$ & $\begin{array}{r}29.5 \\
4.89 \\
10.95\end{array}$ & $\begin{aligned} 10.3 \\
3.58 \\
8.02 \\
<0.05 \\
>0.02\end{aligned}$ & $\begin{array}{r}51.2 \\
7.29 \\
16.34\end{array}$ & $\begin{array}{l}75.4 \\
12.09 \\
27.09\end{array}$ & $\begin{array}{r}24.2 \\
5.17 \\
11.59 \\
<0.01\end{array}$ & $\begin{array}{c}+31.9 \\
4.91 \\
11.0 \\
<0.01\end{array}$ & $\begin{array}{r}+45.9 \\
9.60 \\
21.50 \\
<0.01\end{array}$ & $\begin{array}{c}+14.0 \\
4.53 \\
10.2 \\
<0.1 \\
>0.05\end{array}$ & $\begin{array}{r}847 \\
80.7 \\
180.7\end{array}$ & $\begin{array}{l}770 \\
116.5 \\
261.0\end{array}$ & $\begin{array}{r}77.0 \\
49.0 \\
109.8 \\
>0.1 \\
\end{array}$ \\
\hline $\begin{array}{l}\text { Statistic } \\
\text { with }\end{array}$ & $\begin{array}{l}\text { l* comparison } \\
\text { rale series }\end{array}$ & $\begin{array}{l}\mathrm{t}= \\
\mathrm{p}=\end{array}$ & $\begin{aligned} & 1.53 \\
>0.1 & \end{aligned}$ & $\begin{array}{l}2.2 \\
>0.02 \\
<0.05\end{array}$ & $\begin{array}{l}2.6 \\
>0.01 \\
<0.02\end{array}$ & $\begin{array}{r}1.5 \\
>0.1\end{array}$ & $\begin{array}{r}1.3 \\
>0.2\end{array}$ & $\begin{array}{r}0.6 \\
>0.5\end{array}$ & $\begin{array}{r}0.7 \\
>0.4\end{array}$ & $\begin{array}{r}0.5 \\
>0.5\end{array}$ & $\begin{array}{r}1.1 \\
>0.2\end{array}$ & $\begin{aligned} & 1.19 \\
&>0.2\end{aligned}$ & $\begin{array}{l}0.57 \\
>0.5\end{array}$ & $\begin{aligned} & 0.35 \\
> & 0.5\end{aligned}$ \\
\hline
\end{tabular}

* The mean figures represent averages as described for male series in Table I. The statistical comparison between the male and female series is presented in the lower section of the table.

ever, Ciaranfi and Fonnesu (23), in a recent report, demonstrated an immediate small rise in peripheral blood ketones after infusing sodium acetate intravenously into normal and depancreatized dogs.

Other published observations on the measurement of ketone production in humans are those of Bondy, Bloom, Whitner, and Farrar (24) who reported on splanchnic ketone formation during diabetic acidosis in humans, and of Lipsky and his associates (22) who, as mentioned above, reported on ketone production induced by the infusion of sodium acetate into diabetic patients. Although the techniques applied are similar, comparison of their results with the present study is of limited value since their data were few in number and all were on diabetic subjects. Crandall, Ivy, and Ehni (25) in 1941 estimated hepatic ketogenesis from the hepatic venous-arterial blood ketone levels in fasting and fat-fed angiostomized dogs without directly measuring hepatic blood flow. They were unable to detect any hepatic formation of ketone bodies in dogs fasted less than three days. They attributed their failure to the inaccuracy of their method of ketone analysis.

There are two factors which must be taken into consideration in the interpretation of the results of the present study. Hinkle, Conger, and Wolf (26) have stressed anxiety as a potentiator of ketosis in diabetic patients. It is difficult to state conclusively whether anxiety may have played a role in determining the control NSKP in the present study. All routine steps were taken to minimize anxiety, but certainly it was not eliminated. Nevertheless, the constancy of the results in the large male series makes it seem unlikely that a factor as variable as anxiety could be playing a significant role in the results.

The second factor to be considered is alkalosis. which has been found in animals (27) to increase fasting ketonemia. Moreover, Lipsky and his colleagues (22) have reported increased hepatic ketogenesis after infusing sodium bicarbonate or sodium acetate into humans. It is very doubtful, however, that the $500 \mathrm{ml}$. of sodium octanoate ( $55 \mathrm{mEq}$. of sodium) used in the present study would produce an alkalosis comparable to that observed by other workers (22) after the administration of $238 \mathrm{mEq}$. of sodium as bicarbonate and acetate.

The arterial blood ketone level represents a balance between splanchnic production and peripheral utilization. When the arterial blood level of ketones is constant, it can be assumed that splanch- 
TABLE II-Continued

The metabolic effects of intravenously administered sodium octanoate in five female subjects

\begin{tabular}{|c|c|c|c|c|c|c|c|c|c|c|c|c|c|c|c|}
\hline \multicolumn{3}{|c|}{$\begin{array}{l}\text { Net splanchnic ketone } \\
\text { production } \\
\mu M \text { acetone/min./M² }\end{array}$} & \multicolumn{3}{|c|}{$\begin{array}{l}\text { Net splanchnic oxygen } \\
\text { consumption } \\
\text { ml./min./Mi2 }\end{array}$} & \multirow{2}{*}{$\begin{array}{c}\% \\
\text { conver- } \\
\text { sion sod. } \\
\text { oct. to } \\
\text { ketones }\end{array}$} & \multicolumn{3}{|c|}{$\begin{array}{l}\text { Femoral artery } \\
\text { glucose } \\
m g . / 100 \mathrm{ml} . \text { blood }\end{array}$} & \multicolumn{3}{|c|}{ 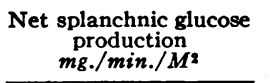 } & \multicolumn{3}{|c|}{$\%$ BSP clearance } \\
\hline $\begin{array}{l}\text { Con- } \\
\text { trol }\end{array}$ & $\begin{array}{l}\text { During } \\
\text { sod. } \\
\text { oct. }\end{array}$ & $\Delta$ & $\begin{array}{c}\text { Con- } \\
\text { trol }\end{array}$ & $\begin{array}{l}\text { During } \\
\text { sod. } \\
\text { oct. }\end{array}$ & $\Delta$ & & Con- & $\begin{array}{l}\text { During } \\
\text { sod. } \\
\text { oct. }\end{array}$ & $\Delta$ & $\underset{\text { Con- }}{\text { Crol }}$ & $\begin{array}{l}\text { During } \\
\text { sod. } \\
\text { oct. }\end{array}$ & $\Delta$ & $\begin{array}{l}\text { Con- } \\
\text { trol }\end{array}$ & $\begin{array}{l}\text { During } \\
\text { sod. } \\
\text { oct. }\end{array}$ & $\Delta$ \\
\hline 47 & 116 & +69 & 29 & 34 & +5 & 8 & 83 & 81 & -2 & 56 & 67 & +11 & 82 & 82 & 0 \\
\hline 175 & 166 & -9 & 41 & 38 & -3 & 0 & 98 & 93 & -5 & 89 & 80 & -9 & 85 & 87 & +2 \\
\hline 149 & 271 & +122 & 33 & 23 & -10 & 14 & 72 & 69 & -3 & 93 & 68 & -25 & 62 & 63 & +1 \\
\hline 25 & 204 & +179 & 42 & 55 & +13 & 21 & 77 & 76 & -1 & 59 & 63 & +4 & 96 & 96 & 0 \\
\hline 32 & 123 & +91 & 32 & 38 & +6 & 11 & 80 & 77 & -3 & 54 & 44 & -10 & 62 & 57 & -5 \\
\hline $\begin{array}{l}86.0 \\
31.5 \\
71.6\end{array}$ & $\begin{array}{r}176.0 \\
28.5 \\
63.8\end{array}$ & $\begin{array}{c}90.0 \\
30.9 \\
69.2 \\
<0.05 \\
>0.02\end{array}$ & $\begin{array}{r}35.2 \\
2.42 \\
5.38\end{array}$ & $\begin{array}{r}37.6 \\
5.13 \\
11.50\end{array}$ & $\begin{aligned} &+ 2.4 \\
& 3.72 \\
& 8.31 \\
&>0\end{aligned}$ & $\begin{array}{c}10.8 \\
3.45 \\
7.73\end{array}$ & $\begin{array}{r}82 \\
4.39 \\
9.84\end{array}$ & $\begin{array}{r}79.2 \\
3.95 \\
8.85\end{array}$ & $\begin{array}{r}-2.8 \\
0.66 \\
1.48 \\
<0.02 \\
>0.01\end{array}$ & $\begin{aligned} 70.2 \\
8.54 \\
19.14\end{aligned}$ & $\begin{array}{r}64.4 \\
5.83 \\
13.06\end{array}$ & $\begin{array}{c}-5.8 \\
6.21 \\
13.92 \\
>0.4\end{array}$ & $\begin{array}{c}77.4 \\
6.74 \\
15.0\end{array}$ & $\begin{array}{l}77.0 \\
7.33 \\
16.43\end{array}$ & $\begin{array}{r}-0.4 \\
2.7 \\
1.2 \\
>0.5\end{array}$ \\
\hline $\begin{array}{r}2.68 \\
>0.01 \\
<0.02\end{array}$ & $\begin{aligned} & 0.92 \\
> & 0.3\end{aligned}$ & $\begin{array}{l}0.95 \\
>0.3\end{array}$ & $>0.5$ & $\begin{array}{r}0.7 \\
>0.4\end{array}$ & $>0.5$ & ${ }_{>0.1}^{1.68}$ & $\begin{aligned} & 0.62 \\
&>0.5\end{aligned}$ & $\begin{array}{r}1.1 \\
>0.2\end{array}$ & $>0.5$ & $\begin{aligned} & 0.29 \\
> & 0.5\end{aligned}$ & $>0.5$ & $\begin{aligned} & 0.28 \\
> & 0.5\end{aligned}$ & $\begin{array}{l}1.05 \\
>0.3\end{array}$ & $\begin{aligned} & 0.728 \\
> & 0.4\end{aligned}$ & $\begin{aligned} & 2.04 \\
> & 0.05 \\
< & 0.1\end{aligned}$ \\
\hline
\end{tabular}

nic production and peripheral utilization are equal. Such a state of affairs existed in this study in the control period, and hence the net splanchnic ketone production, which was estimated directly from splanchnic blood flow and splanchnic blood ketone difference, can be taken as a measure of fasting ketone utilization during this period. It will be recalled that during the control period NSKP varied directly with the arterial blood ketone concentration. Thus utilization was higher when arterial levels were higher. Gammeltoft (28) has made a similar observation. The rising

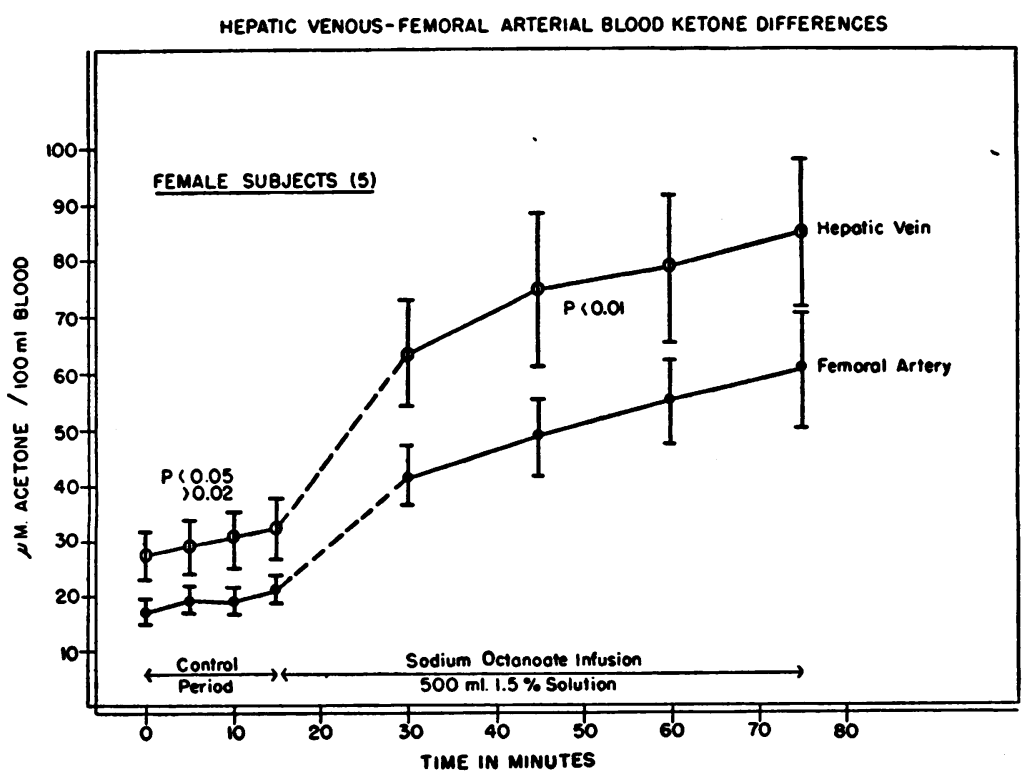

Fig. 5. Hepatic Venous and Femoral Arterial Blood Ketone Levels $(\mathrm{MEAN} \pm$ S.E. $)$ 
and falling arterial blood ketone levels after octanoate infusion prevent one from translating ketone production to ketone utilization during that period.

Too great emphasis should not be placed on the differences in ketogenesis between the male and female groups. The series of five females is small and the irregularities were due chiefly to two of the five. However, other investigators have noted the factor of sex in ketosis, and hence further study is indicated. Peters (29) noted that female humans are more susceptible to ketosis, and Deuel and Hallman (30) observed a greater ketonemia following a high fat diet in fasted female rats than in pair-fed males. Friedemann (31) on the other hand noted that male monkeys fed a high fat diet excreted more ketones than females.

\section{SUMMARY}

1. Utilizing the technique of hepatic vein catheterization, a method has been developed for measuring directly the splanchnic production of ketones in man and permitting an indirect assessment of peripheral ketone utilization.

2. Employing this method a small but significant endogenous splanchnic ketone production was measured in fourteen out of sixteen mildly ill male subjects in the post-absorptive state. This was increased approximately five-fold during the intravenous administration of a ketone precursor, sodium octanoate.

3. Two of five female subjects exhibited a higher basal output of ketone than did the males, but in only one female did the increase in ketone production after sodium octanoate infusion exceed that of the male series.

4. These data should serve as a useful baseline in evaluating the effects of metabolic and hormonal factors on splanchnic ketone production in man.

\section{ACKNOWLEDGMENTS}

We are much indebted to Dr. Laurance Kinsell, Oakland, California, and to the Armour Laboratories, Kankakee, Illinois, for generous supplies of sterile sodium octanoate solution, and to Jane Giblin, Robert Grodner, Irving Kalb, Rita Lang, Leila Holmes, Betty Sally, Dorothy Frederick, Anna Bourne, and Nita Woolever for valuable technical assistance.

\section{REFERENCES}

1. Lipmann, F., Biosynthetic mechanisms. Harvey Lectures, 1948-1949, 44, 99.

2. Lynen, F., and Ochoa, S., Enzymes of fatty acid metabolism. Biochem. et Biophys. Acta, 1953, 12, 299.

3. Lynen, F., Acetyl coenzyme A and the "fatty acid cycle." Harvey Lectures, 1952-1953, 48, 210.

4. Green, D. E., Oxidation and synthesis of fatty acids in soluble enzyme systems of animal tissues. Clin. Chem., 1955, 1, 53.

5. Lipmann, F., Consideration of the role of coenzyme $A$ in some phases of fat metabolism in Fat Metabolism, A Symposium, V. A. Najjar, Ed., Baltimore, Johns Hopkins Press, 1954.

6. Engel, F. L., The endocrine control of metabolism. Bull. New York Acad. Med., 1953, 29, 175.

7. Weinhouse, S., Factors involved in the formation and utilization of ketone bodies. Major Metabolic Fuels. Brookhaven Symposia in Biology, 1952, 5, 201.

8. Margen, S., Michaels, G. D., Boling, L. A., and Kinsell, L. W., Hormonal regulation of fat metabolism. II. Effects of ACTH and certain steroid hormones upon the utilization of infused acetoacetate and octonoic acid. Proc. 2nd Clinical ACTH Conf., J. R. Mote, Ed., Philadelphia, Blakiston Co., 1951, vol. 1, p. 318.

9. Bradley, S. E., Ingelfinger, F. J., Bradley, G. P. and Curry, J. J., The estimation of hepatic blood flow in man. J. Clin. Invest., 1945, 24, 890.

10. Myers, J. D., The hepatic blood flow and splanchnic oxygen consumption of man-their estimation from urea production and bromsulphalein excretion during catheterization of the hepatic veins. J. Clin. Invest., 1947, 26, 1130.

11. Myers, J. D., Net splanchnic glucose production in normal man and in various disease states. $\mathrm{J}$. Clin. Invest., 1950, 29, 1421.

12. Greenberg, L. A., and Lester, D., A micromethod for the determination of acetone and ketone bodies. J. Biol. Chem., 1944, 154, 177.

13. Michaels, G. D., Margen, S., Liebert, G., and Kinsell, L. W., Studies in fat metabolism. I. The colorimetric determination of ketone bodies in biological fluids. J. Clin. Invest., 1951, 30, 1483.

14. Weichselbaum, T. E., and Somogyi, M., A method for the determination of small amounts of ketone bodies. J. Biol. Chem., 1941, 140, 5.

15. Hawk, P. B., Oser, B. L., and Summerson, W. H., Practical Physiological Chemistry, 12th edition, Philadelphia, The Blakiston Co., 1947, p. 875.

16. Mahler, H. R., and Wakil, S. J., Studies on fatty acid oxidation. I. Enzymatic activation of fatty acids. J. Biol. Chem., 1953, 204, 453.

17. Mahler, H. R., Role of coenzyme $A$ in fatty acid metabolism. Federation Proc., 1953, 12, 694. 
18. Lehninger, A. L., and Greville, G. D., The enzymic oxidation of $\mathrm{d}$ - and 1- $\beta$-hydroxybutyrate. Biochem. et Biophys. Acta, 1953, 12, 188.

19. Beinert, $H$., Studies on the fatty acid oxidizing system of animal tissues. II. $\beta$-ketoacyl derivatives of coenzyme A. J. Biol. Chem., 1953, 205, 575.

20. Stern, J. R., Coon, M. J., and del Campillo, A., Acetoacetyl coenzyme $A$ as intermediate in the enzymatic breakdown and synthesis of acetoacetate. J. Am. Chem. Soc., 1953, 75, 1517.

21. Green, D. E., Mii, S., and Mahler, H. R., Studies on the fatty acid oxidizing system of animal tissues. III. Butyryl coenzyme A dehydrogenase. J. Biol. Chem., 1954, 206, 1.

22. Lipsky, S. R., Alper, B. J., Rubini, M. E., Van Eck, W. F., and Gordon, M. E., The effects of alkalosis upon ketone body production and carbohydrate metabolism in man. J. Clin. Invest., 1954, 33, 1269.

23. Ciaranfi, E., and Fonnesu, A., Time-course of injected acetate in normal and depancreatized dogs. Biochem. J., 1954, 57, 171.

24. Bondy, P. K., Bloom, W. L., Whitner, V. S., and Farrar, B. W., Studies of the role of the liver in human carbohydrate metabolism by the venous catheter technic. II. Patients with diabetic ketosis, before and after the administration of insulin. J. Clin. Invest., 1949, 28, 1126.
25. Crandall, L. A., Jr., Ivy, H. B., and Ehni, G. J., Hepatic acetone body production in the dog during fasting and fat feeding. Am. J. Physiol., 1940, $131,10$.

26. Hinkle, L. E., Jr., Conger, G. B., and Wolf, S., Studies on diabetes mellitus: the relationship of stressful life situations to the concentration of ketone bodies in the blood of diabetic and non-diabetic humans. J. Clin. Invest., 1950, 29, 754.

27. MacKay, E. M., Wick, A. N., Carne, H. O., and Barnum, C. P., The influence of alkalosis and acidosis upon fasting ketosis. J. Biol. Chem., 1941, 138, 63.

28. Gammeltoft, A., The significance of ketone bodies in fat metabolism. I. Concentration of ketone bodies in the arterial and venous blood in human subjects during starvation. Acta physiol. Scandinav., 1949, 19, 270.

29. Peters, J. P., Diabetic acidosis. Metabolism, 1952, 1, 223.

30. Deuel, H. J., Jr., and Hallman, L. F., Studies on ketosis. XIX: Further studies on endogenous ketonemia in the rat. J. Biol. Chem., 1941, 140, 545.

31. Friedemann, T. E., Ketosis in primates. II. The ratio of $\beta$-hydroxybutyric acid to acetoacetic acid in the blood and urine. J. Biol. Chem., 1942, 142, 635.

\section{SPECIAL NOTICE TO SUBSCRIBERS}

Post Offices will no longer forward the Journal when you move.

Please notify The Journal of Clinical Investigation, Business

Office, 622 West 168th Street, New York 32, N. Y. at once when you have a change of address, and do not omit the zone number if there is one. 